\title{
Medicine, health and bioethics today and tomorrow
}

\author{
Sinisa Franjic \\ Department of Family medicine at Faculty of Medicine Osijek of Josip Juraj Strossmayer University of Osijek, Osijek, Republic of Croatia
}

\section{Email adress:}

sinisa.franjic@gmail.com

\section{To cite this article:}

Sinisa Franjic. Medicine, Health and Bioethics Today and Tomorrow. International Journal of Biomedical Science and Engineering. Special Issue: Medical Law, Health Law and Bioethics as An Imperative for a Better Tomorrow. Vol. 3, No. 3-1, 2015, pp. 1-5. doi: $10.11648 /$ j.ijbse.s.2015030301.11

\begin{abstract}
Medicine is the entire history of the human race still finding their place alongside men. Allowed him all the joy of life as it should be viewed as a brilliant array of knowledge and skills that enable human quality of life. So it was from the earliest days of human history when its parts considered sorcerers' skills, or all sorts of witchcraft. Today's medicine is considered a modern scientific discipline whose primary task of treatment and protection of human health.
\end{abstract}

Keywords: Medicine, Health, Bioethics, Doctor, Nurse, Patient

\section{Introduction}

Medicine is called a sector of human activity which aims to treatment and rehabilitation of sick and preservation and promotion of health of healthy people [1].

Medicine includes the science of materials, on the function and on the development of man, of all phenomena and events of man's interior and environment that affect health and disease, the lesions in man, then the study of drugs and their respective functions, as well as the art of recognizing, assessment, facilitate or treatment of disease, social rehabilitation of patients, prevent diseases, improve the health conditions of life and improvement of physiological processes and biological evolution of man; she is also professionally execute these skills in individual and social level.

Practice of medicine is not exclusive privilege doctor. It can be, on the contrary, assert that almost no profession that would have a certain meaning for the preservation and improvement of public health [1]. In every profession there are occasional medical component, but all together have the same goal: combating disease and improving human health.

Discourse of nursing in the context of justice and the right to health and health care, in the narrow sense of the exit stricter framework topics, and in the wider it would mean some addressing the border, mostly beyond the mundane aspects topics [2]. Each identity is acquired with relation to other identities, and nursing. However, the outstanding feature of their search in controversial attempts to professionalize such identity: to evaluate and billing attention, care, concern, care, support, smile, word and many other attractions without which it is hard to imagine that identity.

When considering supplementing and completing the knowledge of medical workers, we must point out that much of the necessary knowledge acquired during the study, but at the same time one should not ignore the fact that a certain part of the knowledge acquired during the internship. Interns who do their internship performed in hospitals and wellorganized community health centers have the opportunity to independently, but under the supervision of a mentor, to do many jobs that such students have not worked, on duty in the emergency room, alone solve simple health problems both in hospital and in the clinic and gain confidence in the operation and evaluation of health conditions and health risk [3]. About skills that there may be trained to perfection to speak.

\section{Medical Care and Health}

How is the health care of special importance for the community and society, the state government usually administrative, legislative and economic measures regulating relations between citizens-insured and health care workers, especially in matters of market relations, so that the most frequently speaks of directed oil market [4]. Health care must be continuous which implies a continuing health care for all ages. In this system of health activities should be coordinated with each other and connected [5]. It is very important in the health care of children because it is precisely in this segment 
of protection can be seen that only one form of protection can make a positive shift. The improvement of health care involves a number of medical disciplines and sectors to ensure the comprehensiveness of health care for all citizens of the state.

Health, as well as socio-economic categories, includes in itself the interests of individuals and the interests of society. The relationship of the individual and society towards health history is changing. The nearby village of past health, its protection and improvement were considered individual care and private interests of the individual. Today, however, about the health of almost all over the world speaking as an important public interest, a significant factor of economic and social security and the essential components of economic and social wellbeing. The right to health is programmed as one of the fundamental human rights. This evolution of understanding and treatment of health is a reflection of changed social and economic relations in the modern world [6]. Therefore, here it must be emphasized that in every country health legislation reflects social conditions, general legislation and current health policy and also provide guidance for the organization and management of health services [7]. On the other hand the state of public health and health care directly affected by many other laws except those in the field of health.

With technical progress in medicine on the one hand and extending health insurance to all levels of society on the other hand are connected to the rising cost of maintaining an efficient health care system. Limiting the fixed assets and increased economic responsibility of medical professionals impose relation doctor-patient model contract. Doctor ensuring of arbitrary interpretation of its responsibility, and the patient becomes aware of the limits of service that gets the contract. Notwithstanding the necessity of restructuring in health care, the most painful part of the financial reduction, especially in the Croatian health care, that the administrative procedures reduces the time devoted to patient doctor. You can professionally and morally to be a good doctor and have an innate sense of communication with patients, i. e. be charismatic doctor, but if the patient does not dedicate enough time, you become anonymous authority, creating uncertainty and mistrust of the patient. This course has a detrimental effect on the very doctor because gets the feeling that forced becomes superficial and insensitive [8].

It should be noted that each patient or the patient has certain rights under the Law of Protection of Patients' Rights in accordance with which it is obliged to act all medical staff. This law, in fact, talk about the possibilities that the disposal of each patient, related to its decision on the method and progress of treatment. For the implementation of a patient's desire to keep in mind the cultural differences. The biggest problem that can occur, and it relates to cultural specificities, refers to the impossibility of discussing death, i. e., talk about death in certain cultures taboo, and this issue is avoided. And although cultural differences may be highly expressed in some patients, to avoid over-generalization. The case of each patient should be considered separately [9]. Doctor (and other medical staff) who approach the patient with respect, which has an open approach, which respects cultural diversity, should have no problem in approaching advanced planning patient, when appropriate and in a form that is appropriate in a particular case.

\section{The Tasks of Modern Medicine}

In theory there are several divisions of medicine and we believe that the division of the theoretical and practical medicine in the most important because it speaks of theoretical scientific knowledge and practical application of these scientific findings. Today's modern medical worker, regardless of specialization, in their work must be familiar with the theory and practice, or should know of the existence of different types of diseases and the ways of treatment and suppression, which would mean high-quality application of theory and practice. In further exposition we do not ponder as to us it took away too much space, but we will point out that, before modern medicine ask four questions and that it should be kept. According Grmek, these are:

1) treat and combat disease

2) allow patients to return to normal life

3) prevent the occurrence of disease

4) improve the health of healthy people

\section{Diagnosis}

His observation, measurement and conversation with the patient, the doctor comes to a multitude of different types. Based on the data and their knowledge, experience and skill, the doctor produces information relevant to decision-making and to solve problems. It can be said that information is the result of data processing, where the processing of a combination of a series of operations, for example, comparing, summarizing, calculating, etc. Already when entering the patient in clinic doctor observes his appearance, gait or posture. In the course of conversation learned the reasons of his arrival. Then examined, measured and sent to the laboratory and other tests. Sometimes information, specifically diagnosis, but can be set on the basis of data collected by the doctor observing patients approaching him. Sometimes however need to go several steps to be diagnosed: collect data, set up several possible diagnoses, again look for new data, etc. [1].

\section{Participation in the Modern Scientific Research}

A scientific technology should be given a few notes because it has developed so far and so fast progressing to suppress and individual approaches until recently considered to be extremely advanced. This is why individuals attribute to her achievements and opportunities that it actually does so medical student has the scientific research technology to take a balanced view: there must not underestimate nor 
overestimate. They must not be ignorant despise the opportunities that are available, but also not be mixed medical reality and science fiction [1].

Almost all human and animal cells can be grown today separated from the body, in a dish where they have the ideal opportunity for growth (i. e. the culture in vitro). This enables their detailed study, without the interference signals from other cells or from other parts of the body.

Medical care is based on the scientific evidence in contemporary medical practice holds very important method. Application of this method aims to contribute to a more effective inclusion of published scientific evidence into everyday clinical practice. The traditional paradigm of clinical practice relies on scientific authority, standard approaches to patient care and the answers obtained through direct contact with local experts or in standard reference manuals of external experts. In the new paradigm, based on the scientific evidence, in the process of clinical decisionmaking quality scientific evidence is central, less importance is given to the authority (which does not mean a rejection of what can be learned from colleagues and their experiences), and the task of the doctor regularly to monitor the scientific publications which are unbiased and verifiable manner recorded clinical observations and to know them critically judge [10].

\section{Ethics and Bioethics}

Through all the past period to the present day medicine has greatly progressed. Doctors have always endeavored to new possibilities of diagnosis and care for patients are not conflicting with generally accepted ethical principles. Advances in science and new knowledge in technology have created a number of ethical dilemmas on all issues - from birth to death. Nowadays in medical decisions ethical nature of participation and theologians, philosophers, lawyers, social workers and others. The reason is that the traditional medical ethics based on the Hippocratic Oath has become insufficient to deal with new problems and issues arising from the development of technology and science in general. It was recognized that the creation of rules in the relationship between doctor and patient can not be solely the responsibility of medicine [11].

Ethics as a scientific discipline has several definitions, and by Šegota [12], ethics is the science that studies the morality, his expressions, development, theories, principles and norms. As such experienced application in many areas of social life including medicine. In this domain focus on specific issues related to health services and medical science and is called medical ethics. However, given the complexity of the area covered, medical ethics itself a branch of the more special medical ethics and affirm the ethics of nursing. Within the medical ethics are known not only ethics of medicine or nursing ethics but also ethics of dental medicine, ethics chiropractors, pharmacists ethics, ethics of psychologists and others.

To doctors and other medical staff better trained in their professional work, it is necessary to constantly teaching in clinical medical ethics. Medical professionalism encourages doctors and other medical staff to put patients' interests above their own interests. Stressing professionalism, supporters of these initiatives are expected to medicine and doctors can restore professional autonomy, reduce criticism that the public refers to doctors and help them to re-gain a strong moral position. Before medical teachers raises the crucial question - can you teach medical students and residents concepts of professionalism [13]. The main goal of learning clinical bioethics is to improve the quality of care for patients. It is an undisputed role of bioethical training in clinical medicine bedside. Tom should precede bioethical education in preclinical teaching. However, not moral responsibilities and problems put only bedside. They interfere with the wider community to be educated on basic bioethical knowledge in clinical medicine and this is especially true for services that support health care. Bioethical education in clinical medicine is directed toward a student, doctor and other health care staff, which should be helped to understand that the patient is the center of all interests.

In health care, bioethics and legally sound decision based on the free decision of the patient. Bioethical doctrine of informed consent (informed consent) is based on patient's consent which was preceded by information and proper understanding of the information that could be applied any treatment. Information and lessons must be patient allow you to know the basic facts that have free choice among multiple types medical intervention or the right to refuse the intervention. The patient should be informed of methods of intervention, risks, discomfort and consequences [14].

Patients have a right to expect that information about their health doctors kept confidential. Trust is the foundation of the relationship between doctor and patient. Without belief in confidentiality, patients may doctor denied the necessary information it needs for proper care [15].

An interesting description of bioethics gives prof. Maja Žitinski [16] who says that bioethics addresses ethical issues and dilemmas arising from the rapid development of biotechnology, medicine, politics, law and other fields of human knowledge at the time when the power to be defined in a new way. Some bioethicists narrow judgment only on the morality of medical treatments or technological innovation, while the second extends especially on environmental issues as well as on all other topics oriented towards life. Ideas about the values are not created in a vacuum; they are always generated and elaborated under the influence of power. Due to changes in the distribution of economic and political power on a normative level, man's civil rights are increasingly valued, while the autonomy of the person more respected. The concept of bioethics is usually used in a way that involves medical ethics as its sub-areas. The biomedical ethics examines problems from the point of view strictly oriented towards the clinical approach to the patient, while bioethics same issues viewed from the point of view of more general, philosophical starting points. Namely, if the nature of the patient's clinical situation quite correctly defined, it 
does not mean that the course of action to be morally justified.

\section{Doctor of Family Medicine and Medical Ethics}

The extent and scope of work of doctors in primary health care, so-called family doctor, implies competence and the totality of professional knowledge and skills and the kind of supervision and monitoring of treatment of patients and in other sectors of health care (for example, during their treatment in a hospital, etc.). Already at the first symptoms of the disease, as well as during its development, family doctor considerate patient faces the reality of his situation and it is preparing a new way of life. It is necessary to find and point out the remaining functions, enable the patient to the maximum level of self-care and encourage positive thinking towards a situation in which he found himself. Family should be involved in this process of finding the right deal and avoid the development of the situation in which any member of the community, within the treatment process, the victim felt [17].

One of the more common dilemmas and ethical questions in the context of the practice of family doctor is telling the truth to the patient about his illness. The process of solving problems of this kind implies a good estimate of the patient's psyche and the reaction conditions. The patient in this respect is the special kind of addiction, forced to confide in, and leave knowledge, integrity and compassion doctor [17]. These are the situations within which comes to the fore the complexity of the medical profession, implying nuanced assessment scale - from raids to empathy.

\section{Nurse/Medical Technician and Medical Ethics}

To nurses answer to all professional challenges of modern nursing practice, their work must be based on the latest knowledge and information, but also on basic ethical values which provide them ethical orientation in both general life and professional work. There are two key aspects which determine the authentic values of patient: the first refers to the ethical motivation which has to be above particular values of medical professionals and is directed to the wellbeing of patients. The second is the importance of teamwork in which to take account of the specific competencies of certain professions, as none of them would lose their autonomy or identity. The patient may benefit only from a coordinated teamwork of competent professionals. To nursing ethics respond to current and future biomedical challenges, it is extremely important in nursing education and practice introduction of general and professional ethics. The nursing profession needs appropriate academic and scientific education and only then can deal with theoretical aspects of ethical analysis, argumentation and validation. Nursing ethics is based on health care which is its autonomous area of activity and therefore it must remain within the framework of its original professional ideals [18].

\section{Conclusion}

Medicine is the entire history of the human race still finding their place alongside men. It meant he was all the joy of life because he was with their knowledge and skills allowing for a quality life. So it was from the earliest days of human history when its parts considered sorcerers' skills, or all sorts of witchcraft. Today modern medicine is based on scientific evidence and the primary task is the treatment and preservation of human health.

Medicine includes the science of materials, on the function and on the development of man, of all phenomena and events of man's interior and environment that affect health and disease, the lesions in man, then the study of drugs and their respective functions, as well as the art of recognizing, assessment, facilitate or treatment of disease, social rehabilitation of patients, prevent diseases, improve the health conditions of life and improvement of physiological processes and biological evolution of man; she is also professionally execute these skills in individual and social level.

Health, as well as socio-economic categories, includes in itself the interests of individuals and the interests of society. The relationship of the individual and society towards health history is changing. The nearby village of past health, its protection and improvement were considered individual care and private interests of the individual. Today, however, about the health of almost all over the world speaking as an important public interest, a significant factor of economic and social security and the essential components of economic and social wellbeing. The right to health is programmed as one of the fundamental human rights.

Through all the past period to the present day medicine has greatly progressed. Doctors have always endeavored to new possibilities of diagnosis and care for patients are not conflicting with generally accepted ethical principles. Advances in science and new knowledge in technology have created a number of ethical dilemmas on all issues - from birth to death. Nowadays in medical decisions ethical nature of participation and theologians, philosophers, lawyers, social workers and others. The reason is that the traditional medical ethics based on the Hippocratic Oath has become insufficient to deal with new problems and issues arising from the development of technology and science in general.

Knowledge of medical law, health law and bioethics can ultimately only mean one thing: providing quality health care. That is the goal of every modern society. After formal education, all medical staff has to must go another form of education, and it is continuing training in their profession. Because medicine is an area where almost every day something new happens, with these new all medical stuff need to meet. New scientific findings certainly should be applied in practice as they are designed just for that. This will be achieved another goal and that a satisfied patient. If the patient is satisfied, satisfied with the doctor and others from 
medical staff. It's the only way that leads to a better tomorrow.

\section{References}

[1] Grmek, Mirko Dražen; Budak, Antun: «Introduction to Medicine» (Third, redecorated and supplemented edition), Nakladni zavod Globus, Zagreb, 1996.

[2] Babić, Sanja; Santrić, Vjeko: «Righteousness and the right to health and health care», Medicinski fakultet Sveučilišta u Zagrebu, Zagreb, 1992.

[3] Budak, Antun (and associates): «Famly medicine» (Third, supplemented and changed edition), Gandalf, Zagreb, 2000.

[4] Jakšić, Želimir; Kovačić, Luka i suradnici: «Social medicine», Medicinska naklada, Zagreb, 2000.

[5] Švel, Ivo; Grgurić, Josip: «Health care for children», Školska knjiga, Zagreb, 1996.

[6] Jakšić, Želimir (and associates): «Social medicine» (Practicum II), Medicinski fakultet Sveučilišta u Zagrebu, Zagreb, 1989.

[7] Kovačić, Luka (ur.): «Organization and management in health care », Medicinska naklada, Zagreb, 2003.

[8] Talanga, Josip: «Doctor and patient relationship to medical ethics », Bogoslovska smotra 76 (2006.), br. 1.

[9] Šamija, Mirko; Nemet, Damir (and associates): «Supportive and palliative treatment of cancer patients», Medicinska naklada, Hrvatsko društvo za hematologiju i transfuzijsku medicinu, Hrvatsko onkološko društvo, Zaklada Onkologija, Zagreb, 2010.
[10] Markulin, Helena; Petrak, Jelka: «Medicine based on scientific evidence: The attitudes of health care professionals of a clinical hospital», Liječnički vjesnik, Zagreb, 2010.; Godište 132.

[11] www.pergamena.hr

[12] Šegota, Ivan: «Nursing ethics» (Second supplemented and and amended edition), Pergamena Zagreb, Medicinski fakultet Rijeka, 1997.

[13] Frković, Aleksandra: «Bioethical education in clinical medicine », Metodički ogledi, 14 (2007) 2

[14] Frković, Aleksandra: « Bioethical views on the quality of life. Question distanasia and euthanasia», Socijalna ekologija, Zagreb, Vol. 16 (2007), No. 2 - 3

[15] Foster, Charles: «Choosing Life, Choosing Death. The Tiranny of Autonomy In Medical Ethics And Law», Oxford, Portland, Oregon, 2009.

[16] Žitinski, Maja: «Challenges moral judgments in medical ethics. From utilitarianism and deontology to patient autonomy », Obnovljivi život (63) 3 (2008.)

[17] Fatović-Ferenčić, Stella; Tucak, Antun (eds): «Medical ethics», Medicinska naklada, Zagreb, 2011.

[18] Kalauz, Sonja: «Bioethics in nursing», Medicina 2008, Vol. 44, No. 2 